Article

\title{
Assessing the Vulnerability of Marine Fisheries in China: Towards an Inter-Provincial Perspective
}

\author{
Qi Chen ${ }^{1,2, *}$, Weiteng Shen ${ }^{1}$ and Bing Yu ${ }^{1,2, *}$ (1) \\ 1 School of Business, Ningbo University, Ningbo 315211, China; shenweiteng@foxmail.com \\ 2 Ningbo Ecological Civilization Construction Research Base, Ningbo 315211, China \\ * Correspondence: chenqi2@nbu.edu.cn (Q.C.); yubing1@nbu.edu.cn (B.Y.); Tel.: +86-574-8760-9217 (Q.C.)
}

Received: 2 October 2018; Accepted: 17 November 2018; Published: 20 November 2018

check for updates

\begin{abstract}
China's marine fisheries are undergoing large-scale environmental changes associated with climate change, marine pollution, and overfishing. The assessment of marine fisheries vulnerability has become extremely necessary for fisheries management and sustainable development. However, studies on China's marine fisheries vulnerability remains sparse. This study aimed to provide an analysis of the inter-provincial level vulnerability of China's marine fisheries under multiple disturbances. The vulnerability measure was composed of exposure, sensitivity, and adaptive capacity indicators specific to marine fisheries based on the Intergovernmental Panel on Climate Change (IPCC) definitions. Results showed that Liaoning, Hebei, Fujian, and Hainan provinces appeared to be the most vulnerable; Shanghai appeared to be less vulnerable among China's 11 coastal provinces; and the key sources of vulnerability differed considerably among coastal regions. The high vulnerability regions could be divided into two different patterns according to the combination of exposure, sensitivity, and adaptive capacity, but they all had one thing in common: relatively low adaptive capacity. While some existing coercive measures to reduce dependence on fisheries were found to be helpful in China, the reality showed that appropriate adaptation measures such as improving fishermen's education level and increasing vocational training may be helpful in enhancing the existing policy effectiveness.
\end{abstract}

Keywords: vulnerability; marine fisheries; multiple disturbances; inter-provincial perspective

\section{Introduction}

In recent years, China's marine fisheries have expanded, and the country has become the world's largest producer of wild marine fish [1-3]. Marine fisheries make a significant contribution to food security, create employment, and sustain the coastal economy in China. However, because of the extensive pattern of development, China's marine fisheries are now undergoing multiple anthropogenic threats, such as overfishing, pollution, and land reclamation. It has been estimated that the maximum sustainable fish yield in China's offshore region ranges from 750 to 1100 million tons [4,5]. Nevertheless, since 1998, according to government statistics, the actual offshore catches made in China have been within the range of 1200 to 1300 million tons, which far exceeds the maximum sustainable yield. Overfishing is a long-standing phenomenon in China. China's marine environment is now suffering from the serious problem of the depletion of fishery resources. In regions like the East China Sea, overfishing has been so severe that fishermen are unable to catch fish [6]. In addition, along with the extensive coastal development, the environment of China's coastal waters has been profoundly influenced by land-based pollution in recent decades [7], which has further led to habitat loss and depletion of fishery resources [8,9]. Climate change complicates the challenges currently facing China's marine fisheries and poses an enormous threat to the development of marine fisheries [10-13]. 
In this context, the sustainable development of marine fisheries has become an urgent problem for the Chinese government.

The dilemma of the sustainable development of marine fisheries is considered to be a result of unbalanced development between ecological and social sub-systems based on the theory of social-ecological systems [14]. With the increasing understanding of social-ecological systems, integrating and analyzing various components of coupled human and natural systems has been viewed as key to the control of global sustainability challenges such as climate change, species invasion, water shortages and pollution, biodiversity loss, and the spread of disease $[15,16]$. Vulnerability is used to express the consequences of various potential elements of coupled systems following losses in social-ecological systems, and vulnerability assessment is a form of integrated valuation that assimilates social, ecological, and economic information, providing a standardized framework for risk reduction $[17,18]$.

Many studies have focused on the vulnerability of marine fisheries, and have conducted vulnerability assessments. Numerous studies have attempted to identify ways to achieve the sustainable development of marine fisheries from the perspective of vulnerability. Most of the attention has been given to the vulnerability of marine fisheries against the impacts of climate change, with a focus on global marine fisheries [19,20], national marine fisheries [21,22], and individual regional marine fisheries $[18,23]$. In addition to the vulnerability of marine fisheries against climate change, a few authors have analyzed the vulnerability of marine fisheries against multiple natural and anthropogenic threats. For example, Hughes et al. assessed the national level vulnerability against climate change and multiple anthropogenic threats such as overfishing, land use changes, invasive species, shipping, and pollution from the perspective of food security [24]. Thiault et al. presented an approach that integrates spatial and temporal dimensions into vulnerability assessments and applied it to estimate the social-ecological vulnerability of a small-scale coral reef fishery against multiple socioeconomic, institutional, and biophysical drivers [25]. Previous studies have mainly considered the vulnerability of marine fisheries against the single external threat of climate change, with only a few of them evaluating the vulnerability of marine fisheries to multiple external drivers [24,25]. Most countries and regions, including China, are undergoing multiple threats, and not just climate change [9]. The external drivers of vulnerability can be social or biophysical [26-28]. Therefore, from a practical perspective, it is more realistic to assess the vulnerability of marine fisheries against multiple threats. As the world's largest fishing producer, China is experiencing large-scale ecological changes associated with climate change, pollution, and over fishing. However, to the best of our knowledge, none of the existing studies have specifically considered the vulnerability of China's marine fisheries.

Given the vast territory of China, the vulnerability of marine fisheries may substantially differ among the coastal provinces and cities. In an attempt to comprehensively determine the vulnerability, this study conducted an analysis of inter-provincial level vulnerability focusing on marine fisheries in China's coastal regions. It began by establishing an index system to be used in a vulnerability assessment to consider various external drivers based on Intergovernmental Panel on Climate Change (IPCC) definitions and realistic conditions. Compared to previous studies of the vulnerability to climate change in which only projected climate change was used as the external driver, this study further assessed the vulnerability of marine fisheries against multiple external drivers, including climate change, marine pollution, and overfishing. This provides more comprehensive and realistic analytical information for fisheries managers.

\section{Materials and Methods}

Using a vulnerability assessment framework, this study examined the level of vulnerability of marine fisheries against multiple natural and socioeconomic drivers in China's coastal regions. The coastal area of China spans 11 provinces. From north to south, they are as follows: Liaoning, Hebei, Tianjin, Shandong, Jiangsu, Shanghai, Zhejiang, Fujian, Guangdong, Guangxi, and Hainan (Figure 1). Tianjin and Shanghai are direct-controlled municipalities and have a political stature equivalent to that 
of a provincial government. Due to the lack of data, this study does not include Hong Kong, Macao, and Taiwan.

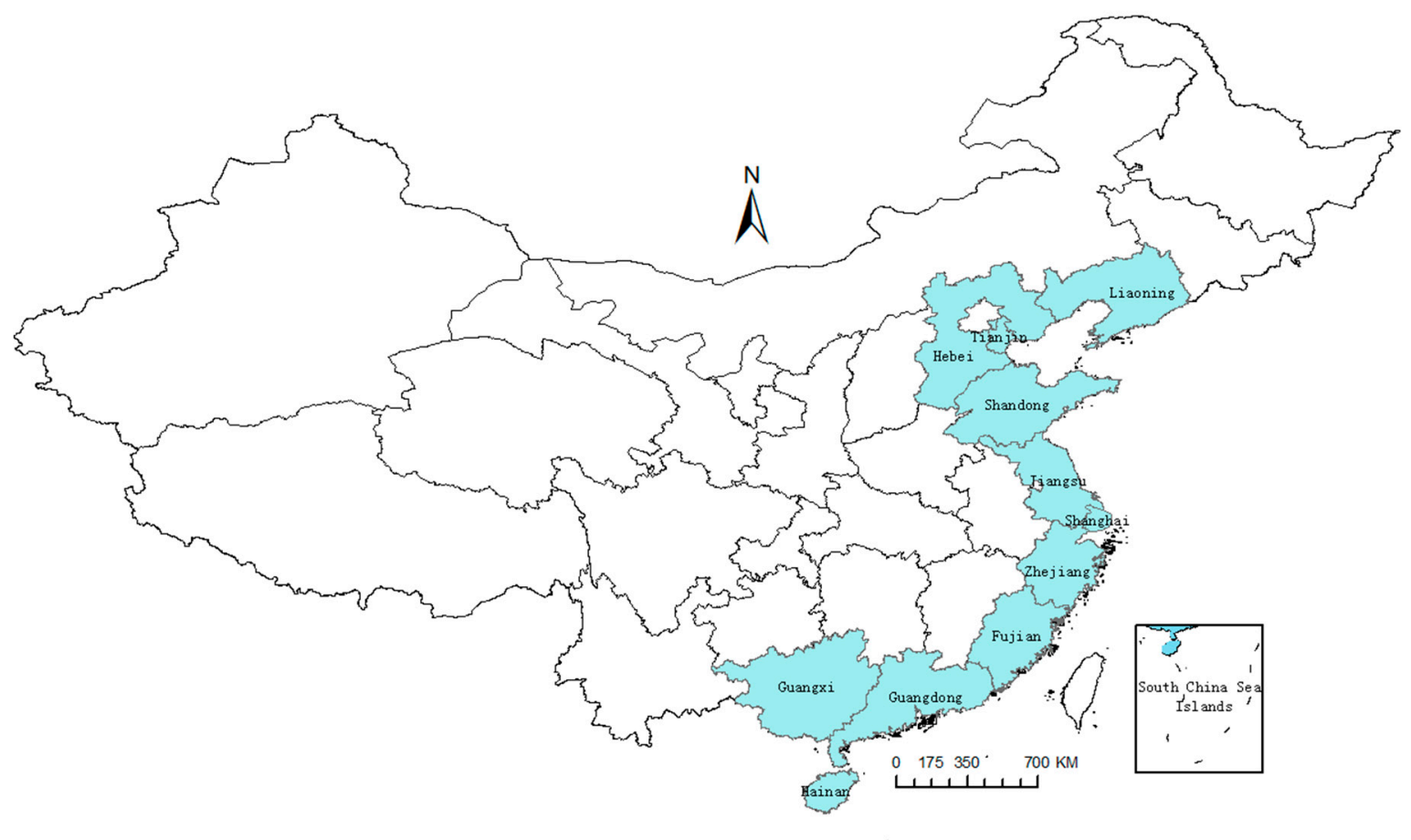

Figure 1. Locations of China's 11 coastal provinces.

According to the IPCC definition [29], vulnerability is a function of the sensitivity and adaptive capacity of a system exposed to a stressor. Based on a generic conceptual model, this study constructed an index system for use in vulnerability assessments that incorporated three components: (1) a region's exposure to environmental change and disturbances; (2) its sensitivity to this change; and (3) its adaptive capacity, or potential to offset the impact of natural and anthropogenic disturbances. Table 1 shows the literature sources used to determine each indicator. After data collection, the level of vulnerability of marine fisheries was calculated using the vulnerability index (VI) [30,31].

\subsection{Exposure}

Exposure was defined as the degree of multiple natural and socioeconomic stresses on marine fisheries. Marine fisheries in different countries or regions are subject to different external threats and therefore their specific exposure indicators are also different [27]. In addition to the general threat of global climate change, China's marine fisheries are also influenced by a variety of complex human disturbances [9]. To scientifically select exposure indicators, we reviewed the relevant literature and consulted 12 Chinese fisheries researchers from the Chinese Academy of Fishery Sciences, the First Institute of Oceanography, the Ocean University of China, and the Ocean University of Shanghai. Finally, we identified climate change, overfishing, and marine pollution as the exposure component indicators and further provided the quantitative variables of these indicators. Sea surface temperature has typically been used as the climate change indicator in previous studies [18-20,32]. In this study, it was measured as the increase in sea surface temperature in 2016 compared with the period of 1993-2011. The values of the increase in mean monthly sea surface temperature in different coastal areas were obtained from the Bulletin of China Marine Environmental Status in 2016 and then summed across the 12 months to provide a single average value. The Bulletin of China Marine Environmental Status is published annually online by the State Oceanic Administration of China and collates statistics on the Chinese marine environment, ecology, main sources of sea pollution, environmental disasters, 
etc. Overfishing was measured as the proportion of the total catch in the middle and low trophic levels in different coastal provinces. The trophic level of the main fishes in the catches from Chinese seas was obtained from $\mathrm{Li}$ et al. [33] and the fractionated trophic levels of catches in different coastal provinces (averaged over 2013-2016) were obtained from the China Fisheries Statistical Yearbook. The sources of marine pollution in China are mainly land-based pollution, oil spills at sea, and self-pollution from mariculture [34,35]. Among these sources of pollution, ocean oil spills have the characteristics of being unforeseen events. According to the Bulletin of China Marine Environmental Status, there were no large-scale oil spills in China's offshore areas during the period of 2012-2015. Self-pollution from mariculture is mainly concentrated in mariculture areas, and thus has a relatively limited impact on wild fish that are widely distributed in offshore areas [36]. Therefore, the main pollution sources affecting China's marine fisheries are land-based pollution, including industrial wastewater, sanitary wastewater, and agricultural wastewater [34]. Considering the lack of data regarding the discharge of sanitary and agricultural wastewater into the sea, in this study, we used industrial wastewater discharges into the sea per unit coastline as the marine pollution indicator, with reference to the relevant literature [37,38]. Industrial wastewater discharge data (averaged over 2012 to 2015) were obtained from the China Marine Statistical Yearbook.

\subsection{Sensitivity}

Sensitivity was defined as the degree of a coastal region's society's dependence on marine fisheries. Marine fisheries contribute to economies and societies by supplying food, increasing economic value, and creating employment. Therefore, sensitivity was measured using three indicators: food dependency, economic dependency, and employment dependency. The high contribution to protein supply, economic value, and employment means a high dependence of economies and societies on the marine fisheries and hence a high sensitivity to multiple external drivers in the coastal region.

Food dependency was represented using fish protein intake as a percentage of total animal protein intake following the methodology used by Barange et al. [39]. The protein content of fish and total animal were derived from the China Food Composition. In addition, according to the consumption of fish and animal (data were obtained from the China Statistical Yearbook, averaged over 2013 to 2016), we calculated the proportion of fish protein intake among all of the animal protein intake. Economic dependency was calculated based on the value of marine fishery industry as a percentage of GDP of coastal regions. The values of the marine fishery industries were obtained from the China Fishery Statistical Yearbook, the GDPs were provided by the China Statistical Yearbook, and both indicators were averaged over 2013 to 2016. Employment dependency was calculated using people working in marine fisheries as a percentage of total employed population. Fisheries employment data were provided by the China Fishery Statistical Yearbook, total employed population were obtained from the China Statistical Yearbook, and both indicators were averaged over 2013 to 2016.

\subsection{Adaptive Capacity}

Adaptive capacity was defined as a coastal region's potential ability to respond to and recover from natural and anthropogenic disturbances. Provinces with high adaptive capacity are less likely to be damaged by external changes and are therefore better able to take advantage of the opportunities to increase their social-economic benefits [20]. In this study, we disaggregated adaptive capacity into four categories: assets, flexibility, learning, and social organization [40]. Assets included two parts: the financial assets and the natural assets. Financial assets were calculated using GDP per capita of coastal regions, and natural assets were represented using adjacent sea area per capita in each coastal province. These data were derived from the China Statistical Yearbook and averaged over 2013 to 2016. Flexibility refers to the range of options a coastal region has to meet social-economic needs if the existing fishery resource declines and marine environment becomes polluted. In this study, flexibility was estimated as a coastal province's life expectancy at birth and GINI index [20,24]. Data for the life expectancy at birth were available from the China Statistical Yearbook. The GINI index, 
a measure of income inequality, was also used as an indirect measure of a region's flexibility, and the data were provided from the survey by Tian (2012) [41] and averaged over 2007 to 2010. Learning was represented using technicians working in marine fisheries as a percentage of total employment in marine fisheries, and the data were obtained from the China Fishery Statistical Yearbook and averaged over 2013 to 2016. In addition, the average adult literacy rate in a province was used as another indirect measure of learning, and the data between 2013 and 2016 were available from the China Statistical Yearbook. Social organization was measured as the Government Effectiveness Index of each coastal province, as developed by $\mathrm{Du}$ and $\mathrm{Li}$ (2012) [42].

\subsection{Calculating Vulnerability}

Full datasets were available for 11 of China's coastal regions. All of the variables were standardized based on maximum values in our dataset and placed on a scale of $0-1$ using the following conversion:

$$
Y_{i j}=\left(X_{i j}-\operatorname{Min} X_{i j}\right) /\left(\operatorname{Max} X_{i j}-\operatorname{Min} X_{i j}\right)
$$

where $Y_{i j}$ was the standardized index value, $X_{i j}$ was the actual value of each coastal province, $\operatorname{Min} X_{i j}$ was the minimum actual value, and $\operatorname{Max} X_{i j}$ was the maximum actual value of actual value.

After that, we calculated the weight of each index using the entropy weight method. The process included, first, the proportion of the $j$-th indicator of the $i$-th evaluation unit calculated as:

$$
P_{i j}=Y_{i j} / \sum_{i=1}^{m} Y_{i j}
$$

Secondly, the entropy index of the $j$-th indicator was calculated(if $P_{i j}=0$, then $E_{j}=0$ ):

$$
e_{j}=-k \sum_{i=1}^{m} P_{i j} \ln P_{i j}, k=1 / \ln m
$$

Thirdly, the difference coefficient of the $j$-th indicator was calculated:

$$
g_{j}=1-e_{j}
$$

Finally, the entropy weight of the $j$-th indicator was calculated:

$$
w_{j}=g_{j} / \sum_{j=1}^{n} g_{j}
$$

The exposure (E), sensitivity (S), and adaptive capacity (AC) indices were measured as follows:

$$
\begin{gathered}
\mathrm{E}=\sum_{j=1}^{3} W_{e j} Y_{e i j} \\
\mathrm{~S}=\sum_{j=1}^{3} W_{s j} Y_{s i j} \\
\mathrm{AC}=\sum_{j=1}^{7} W_{a c j} Y_{a c i j}
\end{gathered}
$$

where $W_{e j}, W_{s j}$, and $W_{a c j}$ referred to the weights of exposure, sensitivity, and adaptive capacity; and $Y_{e i}$, $Y_{s i j}$, and $Y_{a c i j}$ referred to the standardized index value of exposure, sensitivity, and adaptive capacity.

Finally, the Vulnerability Index (VI) was calculated by following the IPCC [43]: 


$$
\mathrm{VI}=\mathrm{E}+\mathrm{S}-\mathrm{AC}
$$

In the calculation of VI, the three components (exposure, sensitivity, and adaptive capacity) were treated equally and each normalized to a $0-1$ scale. The scores of VI were highest for the most vulnerable coastal regions and lowest for the least vulnerable coastal regions.

Table 1. Index system for assessing marine fisheries vulnerability.

\begin{tabular}{|c|c|c|c|c|}
\hline \multicolumn{2}{|c|}{ Component } & Variable & Weight & Reference \\
\hline \multirow{3}{*}{ Exposure } & Climate change & Sea surface temperate & 0.323 & {$[18-20,32]$} \\
\hline & Overfishing & $\begin{array}{c}\text { Catches of middle and low trophic level as } \\
\text { a percentage of total catches }\end{array}$ & 0.369 & [44-46] \\
\hline & Marine pollution & $\begin{array}{l}\text { Industrial wastewater discharge into the sea } \\
\text { per unit coastline }\end{array}$ & 0.308 & {$[36,37]$} \\
\hline \multirow{3}{*}{ Sensitivity } & Food dependency & $\begin{array}{l}\text { Fish protein intake as a percentage of total } \\
\text { animal protein intake }\end{array}$ & 0.204 & {$[18-20,24]$} \\
\hline & $\begin{array}{l}\text { Economic } \\
\text { dependency }\end{array}$ & $\begin{array}{c}\text { Value of marine fishery industry as } \\
\text { a percentage of GDP }\end{array}$ & 0.479 & {$[18-20,32]$} \\
\hline & $\begin{array}{l}\text { Employment } \\
\text { dependency }\end{array}$ & $\begin{array}{l}\text { People working in marine fisheries as } \\
\text { a percentage of total employed population }\end{array}$ & 0.317 & {$[18-20,32,47]$} \\
\hline \multirow{7}{*}{$\begin{array}{l}\text { Adaptive } \\
\text { capacity }\end{array}$} & & GDP per capita & 0.215 & {$[20,24,32]$} \\
\hline & Assets & Adjacent sea area per capita & 0.190 & [47] \\
\hline & & Life expectancy at birth & 0.066 & {$[20,32]$} \\
\hline & Flexibility & GINI index & 0.052 & [24] \\
\hline & Learning & $\begin{array}{c}\text { Technicians working in marine fisheries as } \\
\text { a percentage of total employment in } \\
\text { marine fisheries }\end{array}$ & 0.258 & [19] \\
\hline & & Average adult literacy rate & 0.095 & {$[19,24,25,32]$} \\
\hline & Social organization & Government Effectiveness Index & 0.124 & {$[19,20,24]$} \\
\hline
\end{tabular}

\section{Results}

\subsection{Exposure Analysis}

The exposure, sensitivity, adaptive capacity, and vulnerability indices were calculated according to Equations (6)-(9) (Table 2). For presentation, final indicator scores were categorized by the method of Jenks natural breaks into a four-level scale: high, moderate, low, and very low (Figure 2).

As shown in Figure 2a, the high exposure and moderate exposure regions were located in the Bohai Rim region and Yangtze Delta region. Specifically, Tianjin, Shandong, and Zhejiang were classified as the high exposure (0.447-0.538) coastal regions; and Hebei, Shandong, Jiangsu, and Guangdong had moderate exposure (0.405-0.447). Zhejiang and Shandong were two provinces with the highest marine fisheries yields in China, and recent statistics indicated that about $40-50 \%$ of the marine fisheries yield comes from the two coastal regions. However, the statistics also suggested that the high yield in Zhejiang and Shandong were mainly attributed to the increase in catches of middle and low trophic level species. Therefore, overfishing in Zhejiang and Shandong, by comparison, was more serious than other coastal provinces. As China's two municipalities, Tianjin and Shanghai have developed industries and were recognized as the high exposure regions mainly due to the high discharge of pollution into the sea. Low exposure $(0.230-0.356)$ and very low exposure $(0.144-0.230)$ regions primarily occurred in southern coastal areas, including Fujian, Guangxi, and Hainan provinces. This was chiefly because the South China Sea has a relatively good condition of fisheries resources and marine environment in comparison to the Eastern Seas of China. As an exception, the moderate exposure of Guangdong was mainly attributed to climate change. According to the China Marine Environmental Quality Bulletin and Guangdong Maritime Disaster Bulletin, the sea level in Guangdong rose $10.2 \mathrm{~cm}$ compared to normal years, and the sea surface temperature increase was more than other coastal regions. 


\subsection{Sensitivity Analysis}

As shown in Figure $2 b$, most of coastal regions had high and moderate sensitivity. Regions with high sensitivity $(0.618-0.668)$ and moderate sensitivity $(0.579-0.618)$ were most concentrated in the eastern coastal area where the marine fisheries production was relatively high. Marine fisheries made great contributions to the food supply, the employment obtained, and the coastal economy in these provinces. Low sensitivity $(0.389-0.579)$ regions and very low sensitivity $(0-0.389)$ regions were distributed across the whole study area. Tianjin, Shanghai, and Guangdong were identified as low sensitivity regions due to the low proportion of the value of marine fisheries production and very few people working in marine fisheries. The least sensitive region was located in Hebei province. Apart from two municipalities (Tianjin and Shanghai), Hebei is the region with the smallest sea area and shortest coastline among the coastal areas. Hence, the degree of Hebei's society's dependence on marine fisheries was much smaller than other coastal regions.

\subsection{Adaptive Capacity Analysis}

The spatial pattern of adaptive capacity was mainly concentrated in the central coastal region (Figure 2c). Regions with extremely high adaptive capacity (0.665-0.776) were located in Tianjin, Jiangsu, and Shanghai. As the economic centers of China, Tianjin and Shanghai were more developed than other coastal regions. Here, the social management patterns and fisheries technologies were relatively advanced, and thus, these two municipalities had a strong ability to respond to and recover from external disturbances. Next to Tianjin and Shanghai, the GDP per capita in Jiangsu was the highest. In addition, the high life expectancy at birth, low GINI index, and high average adult literacy rate enhanced Jiangsu's adaptive capacity. Shandong, Zhejiang, Fujian, and Guangdong were identified as moderate adaptive capacity $(0.391-0.665)$ regions due to a combination of high adjacent sea area per capita, high learning ability that was largely the result of the high percentage of fisheries technicians, and relatively high government efficiency. Low adaptive capacity (0.201-0.391) and very low adaptive capacity (0-0.201) regions, such as Liaoning, Hebei, Guangxi, and Hainan, were distributed in the north and south of China's coastal regions, where the level of economic and social development was relatively low.

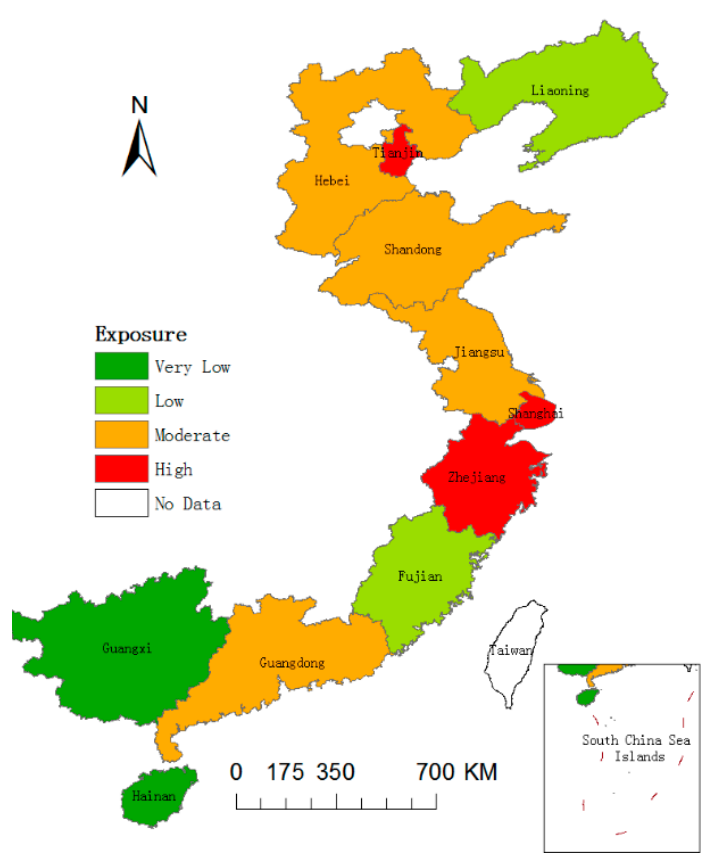

(a)

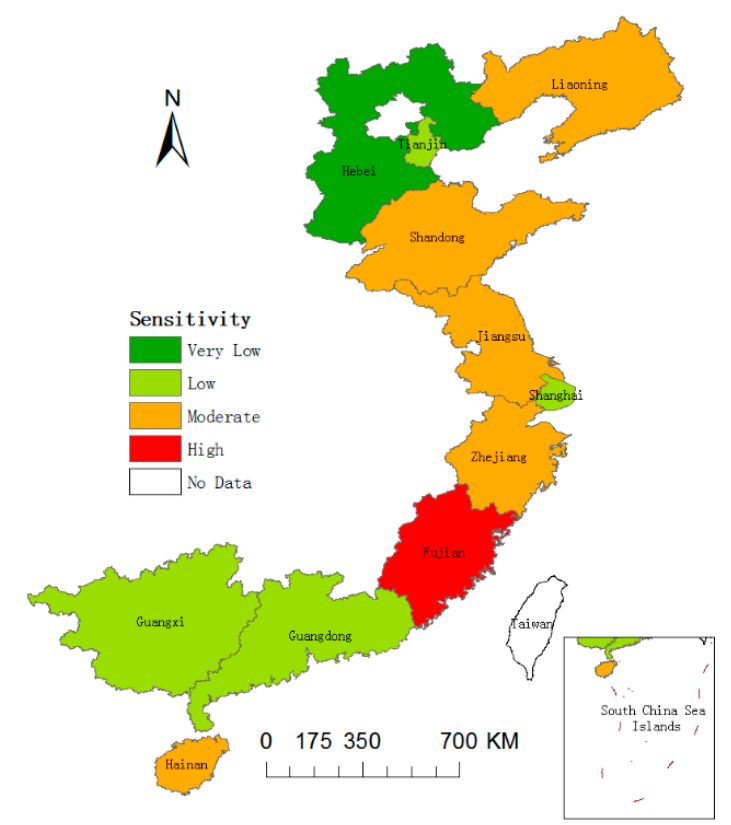

(b)

Figure 2. Cont. 


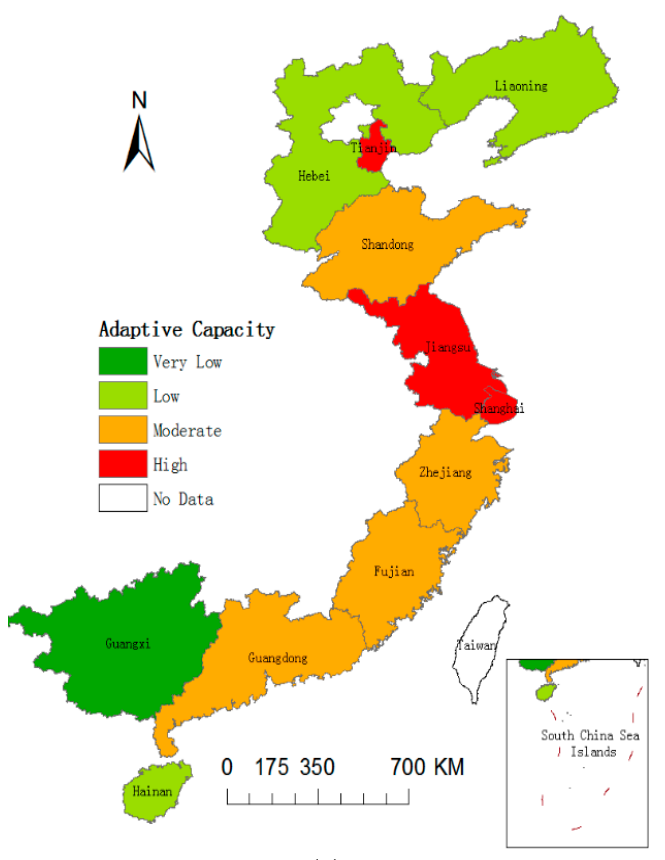

(c)

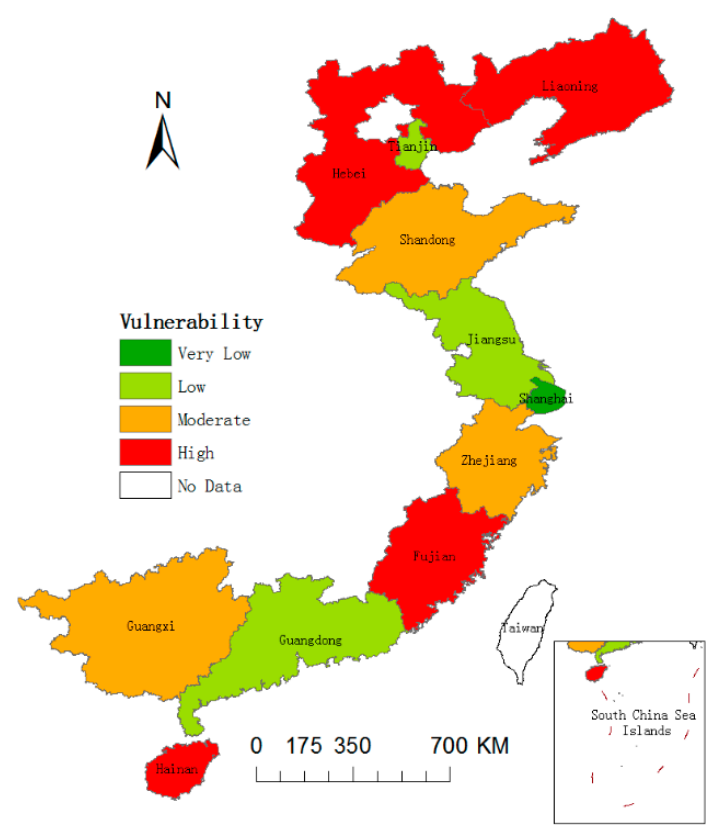

(d)

Figure 2. Spatial pattern of marine fisheries exposure (a), sensitivity (b), adaptive capacity (c), and vulnerability (d).

\subsection{Vulnerability Analysis}

As shown in Figure 2d, there was a wide range in the extent of vulnerability, and overall, the result was not optimistic. Specifically, high vulnerability regions were scattered in the north and south of the study area, including Liaoning, Hebei, Fujian, and Hainan. Shandong, Zhejiang, and Hainan were identified as moderate vulnerability regions. Tianjin, Jiangsu, and Guangdong had low vulnerability, and Shanghai was least vulnerable. Through a comprehensive comparison of the component scores for each province, it was found that regions experienced vulnerability as the result of different combinations of exposure, sensitivity, and adaptive capacity. Regions with similar combinations of these components were likely to be driven by the same sources of vulnerability. Therefore, it is useful to determine effective measures to reduce vulnerability under local conditions by comparing and categorizing the spatial vulnerability of marine fisheries among the Chinese coastal provinces. If the coastal provinces were ranked based only on their vulnerability score, many characteristics of their vulnerability patterns would be covered by the ranking itself [48]. Taking these considerations into account, we identified different vulnerability patterns (Table 2) based on different combinations of exposure, sensitivity, and adaptive capacity, and these were used in the subsequent analysis and discussion.

Liaoning, Hainan, and Fujian could be considered regions with similar vulnerability characteristics, and we classified them as Pattern I. Although these three regions had low or very low exposure, they were identified as the most vulnerable regions due to their relatively high levels of sensitivity and low adaptive capacity. Under the same exposure conditions, the levels of sensitivity in these three regions could not be offset by the lower levels of adaptive capacity. Hebei also had a high level of vulnerability. However, the combination of exposure, sensitivity, and adaptive capacity in Hebei was different from the pattern in Liaoning, Hainan, and Fujian. Although Hebei had a very low marine fishery dependence, the moderate level of exposure together with the low adaptive capacity made it highly vulnerable to multiple stressors. In conclusion, the high vulnerability regions were divided into two different patterns, but they all had a relatively low adaptive capacity.

As the main areas producing marine fish, Shandong, Zhejiang, and Jiangsu all had relatively high levels of exposure, sensitivity, and adaptive capacity. In the context of moderate or high 
exposure to multiple natural and man-made threats, Shandong, Zhejiang, and Jiangsu were relatively dependent on marine fisheries for food and livelihood, while their adaptive capacity was enhanced by relatively strong economic and social indices. However, these three regions experienced different levels of vulnerability due to their different component scores. The moderate adaptive capacity together with moderate or high exposure and moderate sensitivity resulted in Shandong and Zhejiang having a moderate level of vulnerability. Zhejiang, which also had a moderate level of vulnerability, was similar to Shandong, but was highly exposed to external changes. In contrast, the low vulnerability of Jiangsu was mainly due to its high capacity to adapt to the potential impacts.

The exposure and adaptive capacity scores in Tianjin, Shanghai, and Guangdong were higher than the sensitivity scores. We therefore classified these regions into the same category. The high and moderate levels of exposure in Tianjin, Shanghai, and Guangdong were offset by the low dependence on fisheries and relatively high adaptive capacity, and these regions were ranked as low to very low vulnerability. Shanghai was the least vulnerable region among the 11 coastal provinces due to having the lowest level of sensitivity and highest level of adaptive capacity.

The unique combination of exposure, sensitivity, and adaptive capacity in Guangxi led to the province being categorized as the least vulnerable. Guangxi had a combination of very low exposure and low sensitivity that was offset to some extent by its very low adaptive capacity, which was associated with a relatively low GDP per capita expectancy at birth and governance ability. Finally, Guangxi was classified as a moderately vulnerable region under the specific exposure, sensitivity, and adaptive capacity conditions.

Table 2. Pattern classification of vulnerability in China's coastal regions.

\begin{tabular}{cccc}
\hline Pattern Classification & Regions & Exposure-Sensitivity-Adaptive Capacity & Vulnerability \\
\hline \multirow{2}{*}{ Pattern I } & Liaoning & Low-Moderate-Low & High \\
& Hainan & Very Low-Moderate-Low & High \\
& Fujian & Low-High-Moderate & High \\
\hline Pattern II & Hebei & Moderate-Very Low-Low & High \\
\hline \multirow{2}{*}{ Pattern III } & Shandong & Moderate- Moderate- Moderate & Moderate \\
& Zhejiang & High- Moderate- Moderate & Moderate \\
& Jiangsu & Moderate- Moderate-High & Low \\
\hline \multirow{2}{*}{ Pattern IV } & Tianjin & High-Low-High & Low \\
& Shanghai & High-Low-High & Very Low \\
& Guangdong & Moderate-Low-Moderate & Low \\
\hline Pattern V & Guangxi & Very Low-Low-Very Low & Moderate \\
\hline
\end{tabular}

\section{Discussion}

\subsection{Strategies for Reducing the Vulnerability of Marine Fisheries}

Assessing the degree of vulnerability of marine fisheries to natural and anthropogenic disturbances has practical significance for developing effective fisheries management. China is the world's largest country in terms of marine fish production, and it is therefore crucial to identify the vulnerability of China's marine fisheries. However, to the best of our knowledge, a consideration of the vulnerability of China's marine fisheries has only occurred in a few national to global level vulnerability assessments $[19,20,24]$. In studies at the country-level, China has generally been identified as a moderately vulnerable nation. China has a large area of coastal waters and a coastline of over $1800 \mathrm{~km}$ stretching across three climate zones (tropical, sub-tropical, and temperate). Marine fisheries in China's 11 coastal provinces have developed under different natural and social conditions; therefore, different coastal provinces may have different vulnerability patterns. It is therefore necessary to specifically assess the vulnerability of marine fisheries in China's different coastal areas. This study developed an inter-provincial level vulnerability assessment framework focusing on the vulnerability 
patterns of marine fisheries to multiple stressors (climate change, overfishing, marine pollution) in China's coastal regions. The component scores for each province indicated that combinations of exposure, sensitivity, and adaptive capacity factors were likely to be the main drivers of vulnerability. There was no single driver of vulnerability that placed a province most at risk to hazards from multiple disturbances. Vulnerability patterns of marine fisheries in China's coastal regions were obtained based on combinations of exposure, sensitivity, and adaptive capacity.

Regions with a high vulnerability were mainly located in Liaoning, Hebei, Fujian, and Hainan provinces. Although the most vulnerable provinces were divided into two categories based on the component scores, all of these regions shared a common characteristic of having a relatively low adaptive capacity to external stressors in marine fisheries. Liaoning, Fujian, and Hainan appeared to be most vulnerable due to an insufficient adaptive capacity to compensate for sensitivity, while Hebei, which had a very low level of sensitivity, was identified as the most vulnerable province mainly due to an insufficient adaptive capacity to offset moderate exposure. Liaoning, Hebei, Fujian, and Hainan are all relatively underdeveloped regions compared to China's other coastal areas. In these vulnerable regions, it is crucial to improve societal capacity to adapt to the potential impacts. Adaptive capacity is critical for reducing the unsustainable development of marine fisheries. Regions with a high adaptive capacity are less likely to suffer from external disturbances and are therefore better able to achieve sustainable development [49]. Adaptive capacity can generally be predicted by assets, flexibility, learning, and social organization. Policies and development efforts to reduce vulnerability in the four most vulnerable provinces may benefit most from a primary focus on improving these four aspects. Specific actions may include increased investment in fisheries technology, improving governance, promoting public education, reducing poverty, and enhancing the health status of fishermen.

Zhejiang and Shandong are China's two largest provinces in terms of marine fish production. The marine fish production in Zhejiang and Shandong in 2016 was 347.06 and 229.22 million tons, respectively, which accounts for $43.38 \%$ of China's total production. Therefore, the vulnerability level of both regions is directly related to the sustainable development of marine fisheries in China. Our analysis suggests that under conditions of high/moderate exposure and sensitivity, Zhejiang and Shandong could still maintain only a moderate level of vulnerability, mainly due to their moderate adaptive capacity. On account of this, the most effective way to prevent the growth of vulnerability in the two regions is to reduce their dependency on marine fisheries in addition to maintaining a relatively strong adaptive capacity. The Chinese Department of Fishery Administration has formulated a series of measures to reduce the sensitivity of marine fisheries, including a "zero-growth" strategy for total marine catch, a vessel buyback program, the Fishermen Transfer and Fishery Transition Program (with the aim of moving fishermen to other industries, such as mariculture, fish processing, and coastal tourism), and subsidies for distant water fishing vessels [50]. The substitution of mariculture for marine fisheries has historically been a major way to reduce sensitivity. China's overall marine catch has leveled off in the last ten years, and virtually all of the growth in fish production has come from aquaculture [51]. The rapid development of aquaculture has, to some extent, reduced the dependency of food supply, employment, and economic growth on marine fisheries in China's coastal regions. In contrast, although the development of the pelagic fishery in China has also alleviated the economic and employment dependence on marine fisheries, the majority of China's distant water catch has been sold to foreign markets in developed countries and not transported back to China. The industry has therefore contributed less to the local food supply than aquaculture. However, even though such national level industrial restructuring has been effective in reducing sensitivity, many specific programs to reduce dependency in marine fisheries have had limited success at the local level. In the coastal regions of China with large numbers of traditional fishermen, such as Zhejiang and Shandong, marine fisheries still play an important role in the economy and society. In these areas, the "zero-growth" strategy for total marine catch and vessel buyback programs have proven difficult for the local government to implement in practice, and illegal fishing vessels still exist. During 2014 to 2016, the marine catch in Zhejiang and Shandong has continuously increased 
rather than decreased. Because of their low levels of education, traditional fishermen are faced with many livelihood challenges in the process of transformation and have generally responded negatively to the fishermen transfer policy, which has further resulted in Zhejiang and Shandong remaining dependent on marine fisheries for employment. Therefore, policies to increase capacity and diversify livelihoods, including enhanced technical education and an increase in vocational training, could indirectly contribute to a reduction in sensitivity. In conclusion, while some coercive measures to reduce dependence on fisheries have been helpful, there is a need for more comprehensive policy implementation to change livelihood strategies.

\subsection{Prospects for Research}

There have been many studies on the vulnerability of marine fisheries to climate change, but there have been fewer studies on the vulnerability to other stressors. Given that marine fisheries in China are severely affected by overfishing and environmental pollution, this study considered these two indicators in addition to climate change when considering exposure factors. This study developed a set of quantitative indicators for analyzing the vulnerability of marine fisheries to multiple disturbances at a provincial scale. However, the consideration of more external drivers further increases the complexity of vulnerability changes. Similar levels of vulnerability can be caused by different external drivers [28], and therefore vulnerability assessments may not reflect the underlying mechanisms and fail to ensure the effectiveness of vulnerability reduction measures [25]. Therefore, the identification of the interaction between vulnerability and multiple driving factors should be a focus of future research.

\section{Conclusions}

In this study, we provided an analysis of inter-provincial level vulnerability focusing on marine fisheries in China's coastal regions against multiple external threats. To build a scientific vulnerability evaluation system for marine fisheries, we adopted the definitions from IPCC with three components of vulnerability: exposure, sensitivity, and adaptive capacity. Combining the actual conditions of China and the known research results, 13 indicators were selected to assess the spatial vulnerability of China's marine fisheries. In addition, we classified vulnerability patterns of marine fisheries in China's coastal regions based on the combination of exposure, sensitivity and adaptive capacity. Results revealed that Liaoning, Hebei, Fujian, and Hainan provinces appeared to be most vulnerable; Shanghai appeared to be less vulnerable among China's 11 coastal provinces; and the key sources of vulnerability differed considerably among these regions. For regions most vulnerable to external disturbances, their vulnerability patterns could be divided into two types. Liaoning, Fujian, and Hainan were identified as the most vulnerable regions mainly due to a combination of high sensitivity and low adaptive capacity, although they had relatively low levels of exposure. Hebei had very low marine fisheries dependence, but its low adaptive capacity together with moderate exposure resulted in a high level of vulnerability. However, the most vulnerable provinces revealed a common characterization which is a lower adaptive capacity. As China's two largest provinces in terms of marine fish production, Zhejiang and Shandong had relatively high levels of exposure and sensitivity that were nonetheless offset to some extent by their moderate adaptive capacities associated with the relatively strong economic and social indices. The Chinese government's marine fishery management policies mainly focused on the reduction of dependency on marine fisheries in the past, but the reality showed that appropriate adaptation measures such as improving fishermen's education level and increasing vocational training may be helpful in enhancing the existing policy effectiveness.

Author Contributions: Q.C. had the original idea for the study and wrote the paper. W.S. contributed to data collection and calculation analysis. B.Y. contributed to the manuscript modification. All authors have read and approved the final manuscript.

Funding: This paper is financially supported by Humanity and Social Science Youth foundation of Ministry of Education (18YJC790011), National Social Science Fund (16ZDA050), Ningbo Social Science Research Base Project (JD18STWM-1), and K.C. Wong Magna Fund in Ningbo University. 
Acknowledgments: We are grateful for the comments of the anonymous reviewers, which greatly improved the quality of this paper.

Conflicts of Interest: The authors declare no conflict of interest.

\section{References}

1. The Food and Agriculture Organization (FAO). The State of World Fisheries and Aquaculture. 2018. Available online: http:/ / www.fao.org/3/i9540en/I9540EN.pdf (accessed on 1 July 2018).

2. Zhao, W.W.; Shen, H.H. A statistical analysis of China's fisheries in the 12th, five-year period. Aquac. Fish. 2016, 1, 41-49. [CrossRef]

3. Mallory, T.G. Fisheries subsidies in China: Quantitative and qualitative assessment of policy coherence and effectiveness. Mar. Policy 2016, 68, 74-82. [CrossRef]

4. Cai, L. Study of Population Carrying Capacity of Fisheries Resources about Chinese "The New Eastern Part"; China Social Sciences Press: Beijing, China, 2012. (In Chinese)

5. Liang, S.; Chen, Q.; Han, L.M. Study on the assessment of Production Potential of "Marine Food System" in China. Rural Econ. 2018, 5, 49-54. (In Chinese)

6. Liang, C.; Pauly, D. Fisheries impacts on China's coastal ecosystems: Unmasking a pervasive 'fishing down' effect. PLOS ONE 2017, 12, e0173296. [CrossRef] [PubMed]

7. Ren, W.; Ji, J.; Chen, L.; Zhang, Y. Evaluation of China's marine economic efficiency under environmental constraints-An empirical analysis of China's eleven coastal regions. J. Clean. Prod. 2018, 184, 806-814. [CrossRef]

8. Halpern, B.S.; Walbridge, S.; Selkoe, K.A.; Kappel, C.V.; Micheli, F.; D’Agrosa, C.; Bruno, J.F.; Casey, K.S.; Ebert, C.; Fox, H.E.; et al. A global map of human impact on marine ecosystems. Science 2008, 319, 948-952. [CrossRef] [PubMed]

9. Halpern, B.S.; Longo, C.; Hardy, D.; McLeod, K.L.; Samhouri, J.F.; Katona, S.K.; Kleisner, K.; Lester, S.E.; O'Leary, J.; Ranelletti, M.; et al. An index to assess the health and benefits of the global ocean. Nature 2012, 488, 615-620. [CrossRef] [PubMed]

10. Brander, K.M. Global fish production and climate change. Proc. Natl. Acad. Sci. USA 2007, 104, 19709-19714. [CrossRef] [PubMed]

11. Johnson, J.E.; Welch, D.J. Marine fisheries management in a changing climate: A review of vulnerability and future options. Rev. Fish. Sci. 2010, 18, 106-124. [CrossRef]

12. Akpalu, W.; Dasmani, I.; Normanyo, A.K. Optimum Fisheries Management under Climate Variability: Evidence from Artisanal Marine Fishing in Ghana. Sustainability 2015, 7, 7942-7958. [CrossRef]

13. Sumaila, U.R.; Cheung, W.W.L.; Lam, V.W.Y.; Pauly, D.; Herrick, S. Climate change impacts on the biophysics and economics of world fisheries. Nat. Clim. Chang. 2011, 1, 449-456. [CrossRef]

14. Cumming, G.S.; Morrison, T.H.; Hughes, T.P. New directions for understanding the spatial resilience of social-Ecological systems. Ecosystems 2017, 20, 649-664. [CrossRef]

15. Liu, J.; Mooney, H.; Hull, V.; Davis, S.J.; Gaskell, J.; Hertel, T.; Lubchenco, J.; Seto, K.C.; Gleick, P.; Kremen, C.; et al. Sustainability. Syst. Integr. Glob. Sustain. Sci. 2015, 347, 1258832.

16. Herrero-Jáuregui, C.; Arnaiz-Schmitz, C.; Reyes, M.F.; Telesnicki, M.; Agramonte, I.; Easdale, M.H.; Schmitz, M.F.; Aguiar, M.; Gómez-Sal, A.; Montes, C. What do We Talk about When We Talk about Social-Ecological Systems? Lit. Rev. Sustain. 2018, 10, 2950. [CrossRef]

17. Adger, W.N. Vulnerability. Glob. Environ. Chang. 2006, 16, 268-281. [CrossRef]

18. Cinner, J.E.; McClanahan, T.R.; Graham, N.A.J.; Daw, T.M.; Maina, J.; Stead, S.M.; Wamukota, A.; Brown, K.; Bodin, Ö. Vulnerability of coastal communities to key impacts of climate change on coral reef fisheries. Glob. Environ. Chang. 2012, 22, 12-20. [CrossRef]

19. Allison, E.H.; Perry, A.L.; Badjeck, M.; Adger, W.N.; Brown, K.; Conway, D.; Halls, A.S.; Pilling, G.M.; Reynolds, G.D.; Andrew, N.L.; et al. Vulnerability of national economies to the impacts of climate change on fisheries. Fish Fish. 2009, 10, 173-196. [CrossRef]

20. Ding, Q.; Chen, X.J.; Hilborn, R.; Chen, Y. Vulnerability to impacts of climate change on marine fisheries and food security. Mar. Policy 2017, 83, 55-61. [CrossRef]

21. Naim, S.M.; Hidalgo, J.Z.; Arroyo, A.M. Vulnerability to climate change of marine and coastal fisheries in México. Atmósfera 2011, 24, 103-123. 
22. Jacinto, M.R.; Songcuan, A.J.G.; Yip, G.V.; Santos, M.D. Development and application of the fisheries vulnerability assessment tool (Fish Vool) to tuna and sardine sectors in the Philippines. Fish. Res. 2015, 161, 174-181. [CrossRef]

23. Cinner, J.E.; Huchery, C.; Darling, E.S.; Humphries, A.T.; Graham, N.A.J.; Hicks, C.C.; Marshall, N.; McClanahan, T.R. Evaluating social and ecological vulnerability of coral reef fisheries to climate change. PLOS ONE 2013, 8, e74321. [CrossRef] [PubMed]

24. Hughes, S.; Yau, A.; Max, L.; Petrovic, N.; Davenport, F.; Marshall, M.; McClanahan, T.R.; Allision, E.H.; Cinner, J.E. A framework to assess national level vulnerability from the perspective of food security: The case of coral reef fisheries. Eviron. Sci. Policy 2012, 23, 95-108. [CrossRef]

25. Thiault, L.; Marshall, P.; Gelcich, S.; Collin, A.; Chlous, F.; Claudet, J. Space and time matter in social-ecological vulnerability assessments. Mar. Policy 2018, 88, 213-221. [CrossRef]

26. Fischer, J.; Gardner, T.A.; Bennett, E.M.; Balvanera, P.; Biggs, R.; Carpenter, S.; Daw, T.M.; Folke, C.; Hill, R.; Hughes, T.P.; et al. Advancing sustainability through mainstreaming a social—Ecological systems perspective. Curr. Opin. Environ. Sustain. 2015, 14, 144-149. [CrossRef]

27. Bennett, N.J.; Blythe, J.; Tyler, S.; Ban, N.C. Communities and change in the anthropocene: Understanding social-ecological vulnerability and planning adaptations to multiple interacting exposures. Reg. Environ. Chang. 2016, 16, 907-926. [CrossRef]

28. Bonanomi, S.; Colombelli, A.; Malvarosa, L.; Cozzolino, M.; Sala, A. Towards the Introduction of Sustainable Fishery Products: The Bid of a Major Italian Retailer. Sustainability 2017, 9, 438. [CrossRef]

29. Füssel, H.-M.; Klein, R.J. Climate change vulnerability assessments: An evolution of conceptual thinking. Clim. Chang. 2006, 75, 301-329. [CrossRef]

30. Abuodha, P.; Woodroffe, C. Assessing vulnerability to sea-level rise using a coastal sensitivity index: A case study from southeast Australia. J. Coast. Conserv. 2010, 14, 189-205. [CrossRef]

31. Haroon, S.; Purva, J. Assessment of Socio-Economic Vulnerabilities Among Urban Migrants in South-East Delhi, India. J. Stem Cells Regen. Med. 2014, 7, 65-81.

32. Senapati, S.; Gupta, V. Socio-economic vulnerability due to climate change: Deriving indicators for fishing communities in Mumbai. Mar. Policy 2017, 76, 90-97. [CrossRef]

33. Li, J.L.; Cao, K.; Ding, F.; Yang, W.B.; Shen, G.M.; Li, Y.R. Changes in trophic-level structure of the main fish species caught by China and their relationship with fishing method. J. Fish. Sci. China 2017, 24, 109-119. (In Chinese)

34. Zhang, F.; Sun, X.X.; Zhou, Y.; Zhao, C.J.; Du, Z.H.; Liu, R.Y. Ecosystem health assessment in coastal waters by considering spatio-temporal variations with intense anthropogenic disturbance. Environ. Model. Softw. 2017, 96, 128-139. [CrossRef]

35. Zhang, T.H.; Wang, F. Pollution of the Marine Environment and Its Impact on Fisheries. J. Anhui Agric. Sci. 2014, 42, 3654-3655. (In Chinese)

36. Zong, H.M.; Yuan, X.T.; Wang, L.J.; Yu, L.M.; Hu, Y.Y.; Huo, C.L.; Zhang, Z.F. Preliminary evaluation on the nitrogen and phosphorus loads by mariculture in China. Mar. Environ. Sci. 2017, 36, 336-342. (In Chinese)

37. Bi, J.G.; Duan, Z.X. China's marine fishery ecological environment pollution and its treatment countermeasures. Chin. Fish. Econ. 2008, 26, 16-21. (In Chinese)

38. Yu, J.K.; Kong, H.Z. The Rationality Evaluation of Spatial Arrangement of Marine Fishery Based on Marine Carrying Capacity Vision: Exemplify Shandong Blue Area. Econ. Geogr. 2014, 34, 112-123. (In Chinese)

39. Barange, M.; Merino, M.; Blanchard, J.L.; Scholtens, J.; Harle, J.; Allison, E.H.; Allen, J.I.; Holt, J.; Jennings, S. Impacts of climate change on marine ecosystem production in societies dependent on fisheries. Nat. Clim. Chang. 2014, 4, 211-216. [CrossRef]

40. Cinner, J.E.; Fuentes, M.M.P.B.; Randriamahazo, H. Exploring social resilience in madagascar's marine protected areas. Ecol. Soc. 2009, 14, 41. [CrossRef]

41. Tian, W.M. The measure and variation trend of GINI in China's provinces. Econ. Sci. 2012, 2, 48-59. (In Chinese)

42. Du, C.Z.; Zhang, L. Measuring the Local Government Efficiency of the Chinese Provinces with Multiple-target Constrains: Based on the DEA Model with Preference. China Econ. Stud. 2015, 6, 15-25. (In Chinese) 
43. Mccarthy, J.J.; Canziani, O.F.; Leary, N.A.; Dokken, D.J.; White, K.S. Climate Change 2001: Impacts, Adaptation and Vulnerability: Contribution of Working Group II to the Third Assessment Report of the Intergovernmental Panel on Climate Change (IPCC). Available online: http:/ / old.grida.no/climate/ipcc_ tar/wg2/pdf/wg2TARfrontmatter.pdf (accessed on 10 April 2015).

44. Ni, H.E.; Lu, J.H. Construction and evaluation of indicator system for sustainable use of fishery resources in Zhoushan Fishing Ground. Chin. J. Appl. Ecol. 2003, 14, 985-988. [CrossRef]

45. Pauly, D.; Hilborn, R.; Branch, T.A. Fisheries: Does catch reflect abundance? Nature 2013, 494, $303-306$. [CrossRef] [PubMed]

46. Du, J.G.; Cheung, W.W.L.; Ye, G.; Zhou, Q.; Chen, B. Impacts of fishing on the marine mean trophic level in Chinese marine area. Acta Ecol. Sin. 2015, 35, 83-88. [CrossRef]

47. Quiros, T.E.A.L.; Beck, M.W.; Araw, A.; Croll, D.A.; Tershy, B. Small-scale seagrass fisheries can reduce social vulnerability: A comparative case study. Ocean Coast. Manag. 2018, 157, 56-67. [CrossRef]

48. Su, S.; Pi, J.H.; Wan, C.; Li, H.L.; Xiao, R.; Li, B.B. Categorizing social vulnerability patterns in Chinese coastal cities. Ocean Coast. Manag. 2015, 116, 1-8. [CrossRef]

49. Adger, W.N. Social and ecological resilience: Are they related? Prog. Hum. Geogr. 2000, 24, 347-364. [CrossRef]

50. Shen, G.M.; Heino, M. An overview of marine fisheries management in China. Mar. Policy 2014, 44, $265-272$. [CrossRef]

51. Cao, L.; Chen, Y.; Dong, S.L.; Hanson, A.; Huang, B.; Leadbitter, D.; Little, D.; Pikitch, E.; Qiu, Y.S.; de Mitcheson, Y.S.; et al. Opportunity for marine fisheries reform in China. Proc. Natl. Acad. Sci. USA 2017, 114, 435-442. [CrossRef] [PubMed]

(C) 2018 by the authors. Licensee MDPI, Basel, Switzerland. This article is an open access article distributed under the terms and conditions of the Creative Commons Attribution (CC BY) license (http:/ / creativecommons.org/licenses/by/4.0/). 